\title{
Mapping Research on Customer Centricity and Sustainable Organizations
}

\author{
Sergio Pardo-Jaramillo ${ }^{1,2} \mathbb{D}$, Andrés Muñoz-Villamizar ${ }^{1,3, * \mathbb{C}}$, Ignacio Osuna ${ }^{2}$ \\ and Rolando Roncancio ${ }^{2}$ \\ 1 Operations and Supply Chain Management Research Group, International School of Economic and \\ Administrative Sciences, Universidad de La Sabana, Chía 250001, Cundinamarca, Colombia; \\ sergio.pardo@unisabana.edu.co \\ 2 INALDE Business School, Universidad de La Sabana, Chía 250001, Cundinamarca, Colombia; \\ ignacio.osuna@inalde.edu.co (I.O.); rolando.roncancio@unisabana.edu.co (R.R.) \\ 3 Center for Transportation \& Logistics, Massachusetts Institute of Technology, Cambridge, MA 02142, USA \\ * Correspondence: andresmunvi@unisabana.edu.co; Tel.: +1-617-253-4377
}

Received: 4 August 2020; Accepted: 22 September 2020; Published: 24 September 2020

check for updates

\begin{abstract}
Firms are increasingly organized around the client. At the same time, there is customer pressure on green and sustainable organizations. The purpose of this paper is to map the current state of the research in the domain of customer-centric organizations from a sustainability perspective. We conducted a bibliometric analysis from published documents between 1990 and 31 July 2020. Key findings indicate that research on customer centricity and sustainability has increased in recent years, finding some trends and that the topic is structured into three clusters: (1) Sustainable Development, Customer-Centric Perspective, and Sales; (2) Sustainability and Commerce; and (3) Customer-Centricity and Sustainability Trends. The implementation of a bibliometric methodology and the focus given to the definition, the relationships, and the evolution of the three main clusters within the topic are the characteristics that differentiate our study from other publications or reviews in the field of research. In addition, all the documents that refer to practical cases were identified, and the main ones were analyzed, to provide highlights to practitioners who aim to deploy the customer centricity approach in their firms from a sustainable perspective and seeking that the corporate purpose is followed.
\end{abstract}

Keywords: sustainability; customer centric; business strategy; marketing; bibliometric analysis

\section{Introduction}

As firms cannot succeed without worrying about the real needs of their client, they have become customer-centric organizations [1]. Throughout this century, the marketing literature has had a special focus on presenting vast evidence of the organizational economic benefits of focusing on the customer-or, as it has been referred to more recently, customer centricity. Customer centricity is a business strategy that emphasizes placing customers at the center of all the organization activities and that their needs must be understood and properly satisfied [2].

At the same time, and during the past 30 years, companies have been under growing pressure to be completely sustainable [3]. That is, to pay more attention to the social and environmental consequences of activities they deploy. The idea is that the organizations become on sustainable companies, which means that all the collaborators of the companies have the culture to act always in a sustainable way [4]. At the same time, it is necessary that corporate governance includes indicators that measure the environmental, social, and financial sustainability [5]. 
In this context, it seems natural to integrate customer centricity and sustainability in order to guarantee the long-term existence of organizations. Within that perspective, firms should care about the environment, society, and money through different strategies as innovation [6,7], customization of products [8], productivity improvements [9], mindful consumption [10], and considering greater product life cycles [11]. However, to effectively accomplish these strategies, it is necessary for the companies to obtain and analyze the right information at the right time [12] and be coherent with corporate purpose [13].

After analyzing the existing literature, no paper was found that studied the relationship between customer centricity and sustainability from the bibliometric point of view. These bibliometric studies have become a valuable tool in the scientific literature, motivated by access to bibliographic information [14]. As research entities explicitly demand it [15], the objective of this document is to fill this gap and to provide relevant information, without being totalizing, on the state of the art in the literature regarding that relationship [16].

The main contributions of this article are the following: (1) document some relationship between the customer-centric perspective and sustainability from 1990 to July 2020; (2) provide a detailed bibliometric analysis of the above was performed using both the Web of Science and Scopus databases and the VOSviewer software; (3) the most common parameters were used, such as the most prolific authors, the papers with the most influence, the countries where they were published the most, trends, etc.; (4) the conceptualization of all of the above was done using the most common keywords in the subject; and (5) offer suggestions for practitioners in order to be more sustainable and obtain a customer-centric perspective.

The reminder of this paper is organized as follows. The related research is reviewed in Section 2. The proposed methodology is presented in Section 3. Section 4 shows the analysis of the most relevant papers from a bibliometric perspective. Finally, the main conclusions of this study and opportunities for further research are presented in Section 5.

\section{Literature Review}

Our research is built on the existing literature about marketing-focusing on customer centricity-and strategy literature about sustainability. During the time covered by our study of the documents of this research, several concepts have been developed. In the following paragraphs, we present the most relevant constructs and concepts that are that make a literature review of the main topics necessary to facilitate the reader's understanding of the relationship between the customer centricity and sustainability.

\subsection{Customer Centricity}

The first concept of the study is a customer-centric organization or customer centricity. It was born in 1954 when Drucker [17] said, "It is the customer who determines what a business is, what it produces, and whether it will prosper". Moreover, around those years in a book titled "Quality and Competition", its author, Lawrence Abott [18], claimed "What people really desire are not products but satisfying experiences", highlighting the importance of a customer- rather than product-centric approach. Therefore, several marketing academics follow, until today, such as Theodore Levitt, who proposed that "the purpose of a business is the creation and maintenance of customers" [19]. However, only until the 1990s, the concept of a customer-centric organization or customer centricity began to develop as a force in the marketing literature using the term market orientation. For instance, Narver and Slater [20] show that market-oriented companies are more profitable than non-market-oriented companies, even in undifferentiated products or commodities. Therefore, during the 1990s, researchers using what we call today a customer-centric approach suggested that organizations must be focused around the markets they serve [21]. Sheth, Sisodia, and Sharma [1] approach customer centricity as the understanding and delivering value to individual customers rather than mass or target markets. This focus has been 
strengthened with the availability of individual-level customer data which relates customer-centric marketing actions with customer response.

The focus on the economic performance of a firm, due to a customer centric strategy, has a long tradition in marketing literature. Krasnikov and Jayachandran [22], using a meta-analytic approach, find that the correlation of firm's economic performance is stronger with commercial capabilities than Research and Development, or Operations capabilities. One of the possible explanations is that customer satisfaction is a well predictor of firms' cash flows, sales growth, gross margins, and shareholder return [23,24]. Moreover, the meta-analysis study performed by Fang et al. [25] concludes that moving from a product centric to a service centric business add to shareholder value.

Later, researchers evolving Sheth, Sisodia, and Sharma [1] approach, proposed to understand the concept of customer centricity as the way to serve each client as an individual and deliver what they really want, their main objective being to maximize efficiency and effectiveness at the client level [26]. If the organizations want to achieve this, they should build in the same direction the customer-centric organization and a corporate culture that prioritize the above [27]. To do so, it is important to identify a four-stage process to develop a customer-focused organizational culture [28]. Merging the desirable customer response at the individual level and the firm perspective of customer centricity, Fader [29] defines customer centricity as a strategy that aligns the needs of its most valuable customers with the company's products and services to maximize long-term financial value.

In the organization's alignment process, organizational structure should be modified to achieve such firm objectives at customer level such as customer satisfaction and economic benefits as has been shown in past research. However, according to Lee, Kozlenkova, and Palmatier [30], and Lee et al. [31], a customer-centric organizational structure increases customer satisfaction but degrades the organization's economic performance adding coordinating costs that are not present in a product-centric structure. Therefore, despite the vast evidence about the economic benefits of having a customer focus within the organization, moving the organizational structure to a customer-centric approach might have some shortcomings.

Despite the shortcoming presented above, due to recent changes in customer needs and wants, such as technological advances or greater concern about the environment [32]. Gaurav and Shainesh, [2] pointed out that it is necessary to adopt a customer-centric perspective. In fact, customers' concern about the environment goes in line with identifying sustainability as a new megatrend [33], and, therefore, it is critical to continue the development of the construct customer centricity from an organizational standpoint, and it is very attractive to co-relate it with sustainability.

\subsection{Sustainability}

The concept of sustainability emerged in 1987 [34] and is defined as that quality that guarantees the long term, securing the present without compromising the future or ensuring the present without compromising the future, and that prevents the world from collapsing suddenly and uncontrollably [35]. Sustainability has the connotation of privilege the "triple bottom line" responsibility: economic, environmental, and social perspectives [36,37]. Likewise, in recent years, the need to seek Shared Value has been incorporated. This concept helps organizations to define operational policies and practices that improve the competitiveness of companies, and simultaneously help to solve specific problems. That is, to seek the economic and social advancement of the communities around the same organizations [38].

\subsection{Customer Centricity and Sustainability Relationship}

Given customers' emerging concern about the environment and the boarder scope of the sustainability literature that adds to the economic perspective an environmental and social perspectives, the relationship between customer centricity and sustainability is desirable. In this line of thought. Sheth, Sethia, and Sriniva [10] introduce the concept of "Custom-Centric Sustainability" where encourages to always keep in mind the strategy of being focused on customers and at the same time 
having a long-term perspective [39] and with the involvement of managers [40]. It is important to note that the opinion of the stakeholders should be reflected [41] so that all the activities of the organizations have sustainability as the main criterion.

The aforementioned literature provides valuable information on the state of the art and some benefits on the customer centricity and sustainability integration. However, to the best of our knowledge, there is no bibliometric analysis that collectively explores and maps the available literature on customer centricity and sustainability. As the application of bibliometric studies has been widely extended in the academy with the aim of categorizing and understanding the trends and on the vast amount of scientific production [15], the aim of this paper is to fulfil this gap in the literature.

\section{Methodology}

Bibliometric studies are used as a research technique that studies bibliographic material from a quantitative perspective $[15,42,43]$. These analyzes are based on reliable data such as indexed publications. In any case, these analyzes are based on a solid source of knowledge and not on the opinion of different experts [44]. This methodology has been used in research in the world of administration and helps to improve and understand the theory behind various related areas such as information systems in management, international management, logistics, etc. [45].

Within this methodology it is necessary that all the published material of customer centricity and sustainability can be used in such a way that the different researchers can find the latest advances and trends in these areas [46]. It is very interesting to see how, with the latest advances in technology, the development of bibliometric investigations has been facilitated in a very clear way, which has made them increasingly popular [47].

Taking into account all the databases available, it was decided to carry out the bibliometric study using the two most important scientific databases, i.e., Web of Science and Scopus. Web of Science (www.webofknowledge.com) is "the world's most trusted publisher-independent global citation database" [48], while Scopus (www.scopus.com) is the "largest abstract and citation database of peer-reviewed literature: scientific journals, books, and conference proceedings" which indexes thousands of publications and conference papers in the Management area [49]. Table 1 contains a summary of the methodology used in this research.

Table 1. Summary of the Methodology.

\begin{tabular}{|c|c|}
\hline Unit of Analysis & $\begin{array}{l}\text { Relevant Articles, Conferences Papers, and Reviews Whose Main } \\
\text { Content Focuses on the Links between Customer Centricity and } \\
\text { Sustainability }\end{array}$ \\
\hline Total number of documents evaluated & 218 (72 on Web of Science) (204 on Scopus) \\
\hline Period of Analysis & 1990 to 31 July 2020 \\
\hline Type of Analysis & Qualitative and quantitative \\
\hline Search Engines & Web of Science and Scopus \\
\hline Equation & $\begin{array}{c}\text { ((“Customer centricity" OR “Customer-Centric" OR “Customer } \\
\text { Experience") AND (“Sustainable Organization" OR } \\
\text { "Sustainability" OR “Sustainable Firm" OR “Sustainable } \\
\text { Development" OR “Environmental" OR “Natural Resources")) }\end{array}$ \\
\hline Software & VOSviewer \\
\hline
\end{tabular}

To build the Equation presented in Table 1, multiple queries were made in the Web of Science and Scopus search engine, combining all the relationships of customer centricity on the one hand, and, on the other, combining all the relationships of sustainability, having to take into account the article title, the abstract, and the keywords. Those results were filtered, using the same Web of Science and Scopus tools, by relevance, number of times they have been cited, year of publication, and keywords. In the same way, a text mining software called VOSviewer, developed by the University of Leiden [50], was used, which served to detect repeated non-relevant terms and to organize the relationships between the common terms found. 
The referred search found a total of 218 publications between 1990 and 31 July 2020. From the 218 publications, 146 are indexed in Scopus only, 5 are indexed in Web of Science solely, and 67 are indexed in both databases. The Results and Discussion will be presented in the next section.

\section{Results and Discussion}

A study of these characteristics combines science mapping, performance analysis as main procedures [51]. The science mapping procedure shows in a graphic representation how different scientific actors relate to each other [52], for example, the co-occurrence of keywords [46], the evolution of concepts over time, and heat maps of the most used terms. The performance analysis procedure descriptively shows academic assets (e.g., research centers, main research countries, etc.) based on citation indexes [44]. Finally, we also propose a case study analysis in order to quantify real-life implementations, overview the most studied industries, list the most frequent research methodologies implemented, and propose some managerial insights regarding Customer Centricity and Sustainable Organizations. This mapping research will be presented in detail next.

\subsection{Annual Citation and Most Cited Papers}

In Figure 1 it can be seen how the first paper that speaks about customer-centric experience and "sustainability" was published in 1990, showing the relationship with the life cycle of products [53]. Papers on the subject are not published until 2001 when 1onedocument researching the subject of this investigation was given light.

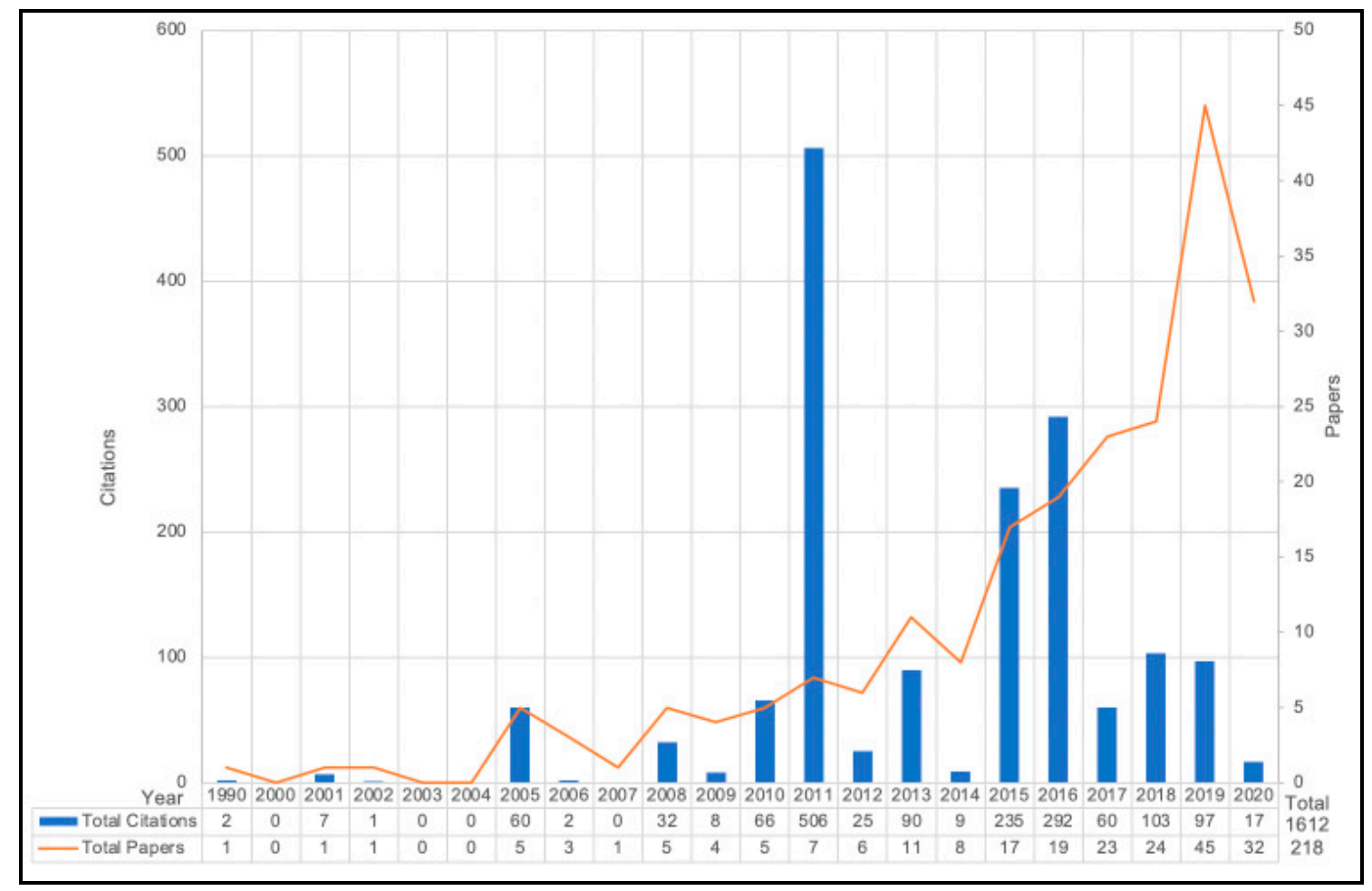

Figure 1. Total Documents/Total Citations.

In 2001, it begins to see a slight growth in publications that show the relationship between the customer-centric perspective and sustainability, with a gap in 2003 and 2004. This continued growth reaches its maximum expression in 2019 with the Publication of 45 documents and continues with the same trend in 2020, where 32 publications had already been reported in the first seven months of the year. Regarding the number of citations, there is no clear upward trend before 2010. However, after the 
publication of the most cited paper (see Table 2), the number of citations has grown exponentially to nearly 911 until the end of 2019.

Table 2. Principal Papers.

\begin{tabular}{|c|c|c|c|}
\hline Title & Authors & Year & TC \\
\hline $\begin{array}{l}\text { Mindful consumption: A customer-centric approach to } \\
\text { sustainability }\end{array}$ & $\begin{array}{l}\text { Sheth, J.N., Sethia, N.K., } \\
\text { Srinivas, S. }\end{array}$ & 2011 & 381 \\
\hline $\begin{array}{l}\text { Co-creation and higher order customer engagement in } \\
\text { hospitality and tourism services: A critical review }\end{array}$ & $\begin{array}{l}\text { Chathoth, P.K., Ungson, G.R., } \\
\text { Harrington, R.J., Chan, E.S.W. }\end{array}$ & 2016 & 122 \\
\hline $\begin{array}{l}\text { The co-creation experience from the customer perspective: } \\
\text { Its measurement and determinants }\end{array}$ & Verleye, $\mathrm{K}$. & 2015 & 102 \\
\hline $\begin{array}{l}\text { Sustainable leadership practices for enhancing business } \\
\text { resilience and performance }\end{array}$ & Avery, G.C., Bergsteiner, H. & 2011 & 65 \\
\hline Effect of servicescape on customer behavioral intentions: & & & \\
\hline $\begin{array}{c}\text { Moderating roles of service climate and employee } \\
\text { engagement }\end{array}$ & Chang, K.-C. & 2016 & 61 \\
\hline IT-Related Service: A Multidisciplinary Perspective & Huang, M.-H., Rust, R.T. & 2013 & 53 \\
\hline $\begin{array}{l}\text { Embracing sustainability: Information technology and the } \\
\text { strategic leveraging of operations in third-party logistics }\end{array}$ & Jeffers, P.I. & 2010 & 51 \\
\hline $\begin{array}{c}\text { Impact of corporate social responsibility initiatives on } \\
\text { Taiwanese banking customers }\end{array}$ & McDonald, L.M., Lai, C.H. & 2011 & 45 \\
\hline $\begin{array}{c}\text { From sustainability to customer loyalty: A case of full } \\
\text { service hotels' guests }\end{array}$ & Chen, R.J.C. & 2015 & 41 \\
\hline $\begin{array}{c}\text { The Effect of Customer-Centric Green Supply Chain } \\
\text { Management on Operational Performance and Customer } \\
\text { Satisfaction }\end{array}$ & $\begin{array}{c}\text { Chavez, R., Yu, W., Feng, M., } \\
\text { Wiengarten, F. }\end{array}$ & 2016 & 40 \\
\hline
\end{tabular}

Note: $\mathrm{TC}=$ Total Citations.

As shown in Table 2, "Mindful Consumption: A customer-centric approach to sustainability" [10] during the research period it has 381 citations, and therefore the number of references will impact the analyzes that will be made later. This paper develops the concept of Customer Centricity Sustainability and suggests that the best way to live it is to make customers aware of mindful consumption, which means that customers must be aware of themselves, the community, and the environment.

Continuing with some changes in the trend explained above, in 2015 a paper developed some metrics that help measure customer experience from an environment-centered perspective [54], reaching 102 citations. Where it is shown that when customer participation in the creation of products is taken into account, a better experience is achieved, and there is a greater possibility of reaching different types of consumers.

During 2016 a paper with 122 citations develops from a broad point of view some characteristics that in the hospitality sector are key for customer engagement and determines sustainability as one of them [55]. These ideas are produced after a review of the literature. A framework is developed that includes key categories that must always be considered in the co-creating process of products and services.

Avery and Bergsteiner [56] in "Sustainable leadership practices for enhancing business resilience and performance", with 65 citations, speaks of sustainability as a factor to achieve higher performance and high value for multiple stakeholders. A model for applying over the business as usual is developed that seeks that the managers of the organizations seek high performance and resilience from the perspective of sustainability.

With 61 citations, the consumer experience is related to the proper management of collaborators [57]. It is shown that if the above is not taken into account, it will be very difficult for the companies to achieve success. This can be measured with a model that examines the relationship between employees, customers, and the company. The connections between each role are enabling promises, making promises, and keeping promises must be made. 
The following papers range from 40 to 53 citations and, refer leveraging information technologies, and IT services to achieve the customer-centric perspective and sustainability [12,58]; the need to have Corporate Social Responsibility [59]; the link between the implementation of the customer-centric green supply chain management and the environmental policy [9]; and the assessment of customers for environmentally friendly policies as a criterion of loyalty [60].

\subsection{Keyword and Clusters Analysis}

As mentioned before, the co-occurrence of keywords is analyzed through VOSviewer [50]. In the 218 papers, 1589 keywords were identified, of which 106 were used in the analysis since they fulfilled the requirement of having at least three occurrences. Figure 2 shows the three dominant clusters. The components of each cluster are presented in Table 3. The first cluster (red) is led by Sustainable Development, Customer-Centric Perspective, and Sales, the second cluster (green) enclose Sustainability and Commerce, and the third cluster (blue) encompasses Customer-Centricity and Sustainability Trends.

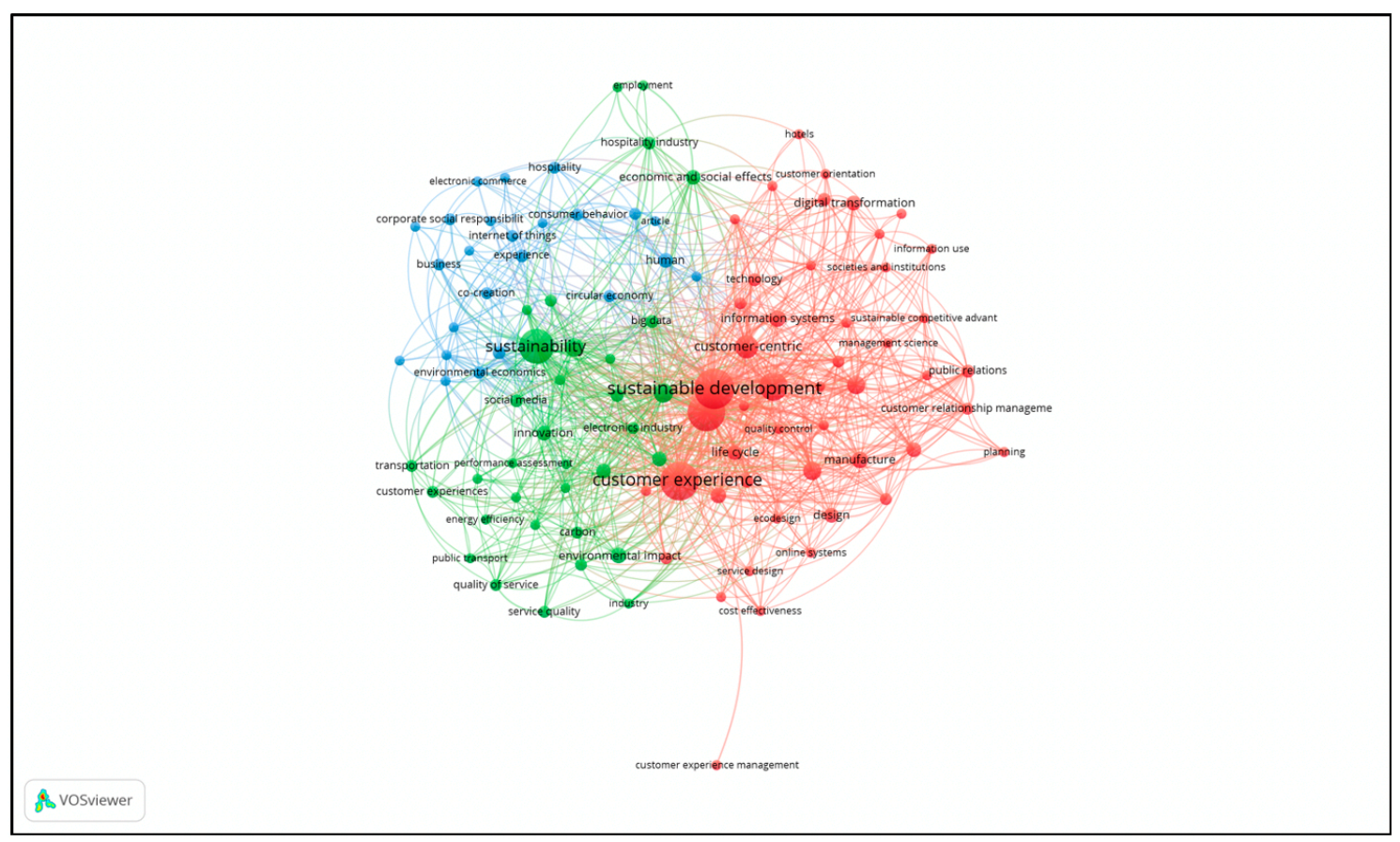

Figure 2. VOSviewer/Co-occurrence of Keywords.

In Cluster 1, 48 concepts are related to "Sustainable Development", the "Customer-Centric" perspective, "Customer Satisfaction" and "Sales". The "Sustainable Development" is understood as the set of practices to achieve sustainability [56], the "Customer-Centric" perspective as emphasizing the service in terms of revolving around the customer, to maintain the relationship with the firm [58]. Closely related to the above, "Customer Satisfaction" shows that the strategy is adequate so that the client is happy with the company and ultimately that centrality is achieved [61]. In the same way, it is seen how it is strongly related to the sales of the companies [62], the design of the goods [63,64], decision making [65], maintaining competitive advantages, and increasing the life cycle of products [66].

It is very interesting as in Cluster 2, where "sustainability" is incorporated in the "triple bottom line" perspective where the performance of companies is not only based on economic criteria, but the environmental and social impact must be taken into account [10]. In this cluster, the relationship between 34 different concepts is shown, among which the use of marketing stands out [16]; the quality of the service [67]; and a very interesting topic where the use of Information, Communication Technology, and Big Data is promoted [68,69]. 
Table 3. Clusters.

\begin{tabular}{|c|c|c|}
\hline Color/Label & Items & Keywords (Occurrences; Link Strength) \\
\hline $\begin{array}{l}\text { (1) Red/Sustainable } \\
\text { Development, } \\
\text { Customer-Centric } \\
\text { Perspective, and Sales }\end{array}$ & 48 & 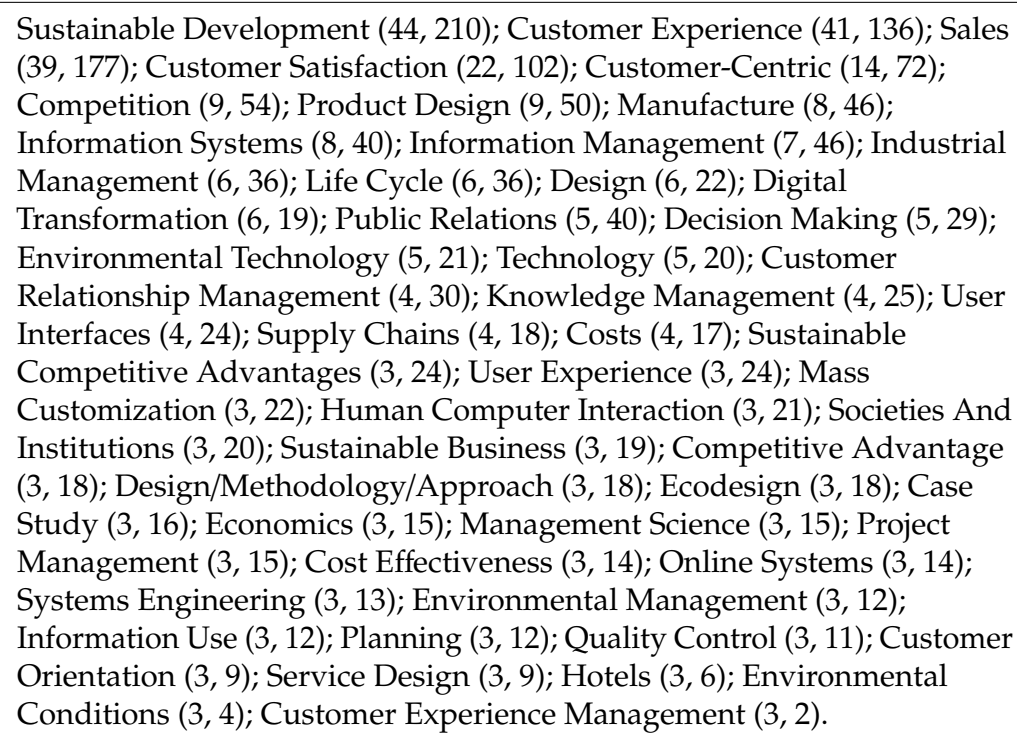 \\
\hline $\begin{array}{l}\text { (2) Green/Sustainability } \\
\text { and Commerce }\end{array}$ & 34 & 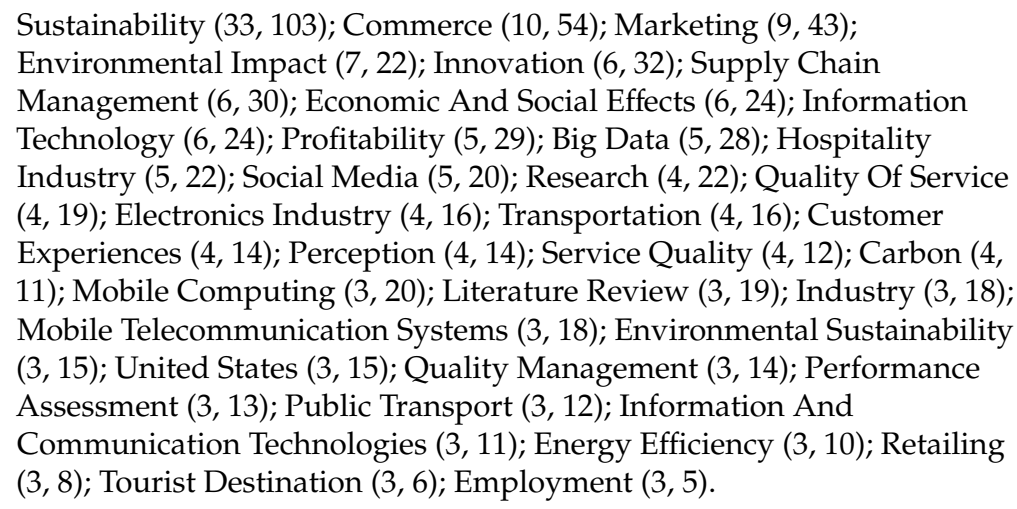 \\
\hline $\begin{array}{l}\text { (3) } \\
\text { Blue/Customer-Centricity } \\
\text { and Sustainability } \\
\text { Trends }\end{array}$ & 24 & 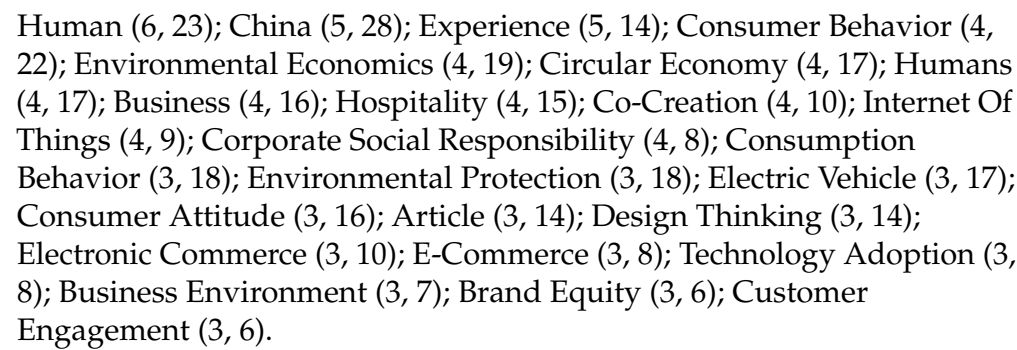 \\
\hline
\end{tabular}

Taking into account the need for information at the right time, the Big Data approach $[58,68,70,71]$ and the utilization of some Artificial Intelligence techniques [72,73] are able to effectively and efficiently manage and analyze the vast amount of customer data [3]. This will bring as a benefit that customers are increasingly loyal to firms [60] and communication channels between organizations and customers are more efficient [74], and therefore a more effective client centrality [75].

Additionally, in Cluster 3, which has 24 keywords, the "Customer Experience Trends" and "Sustainability Trends" appears as the predominant concepts, which has a direct relationship with new developments. In this case, the customer centricity and sustainability help ensure that the products generate a sensation that is pleasing to the human senses at the time of consuming it [76]. Corporate Social Responsibility [26] plays a very important role and some concepts take relevance, such as Circular Economy [77], Internet of Thing [78], Design Thinking [79], E-Commerce [80], and Customer Engagement [55,81]. 
Figure 3 presents a heat map that shows the intertwining between the most frequent keywords (concepts), including the integration between "Customer Centricity" and "Sustainability".

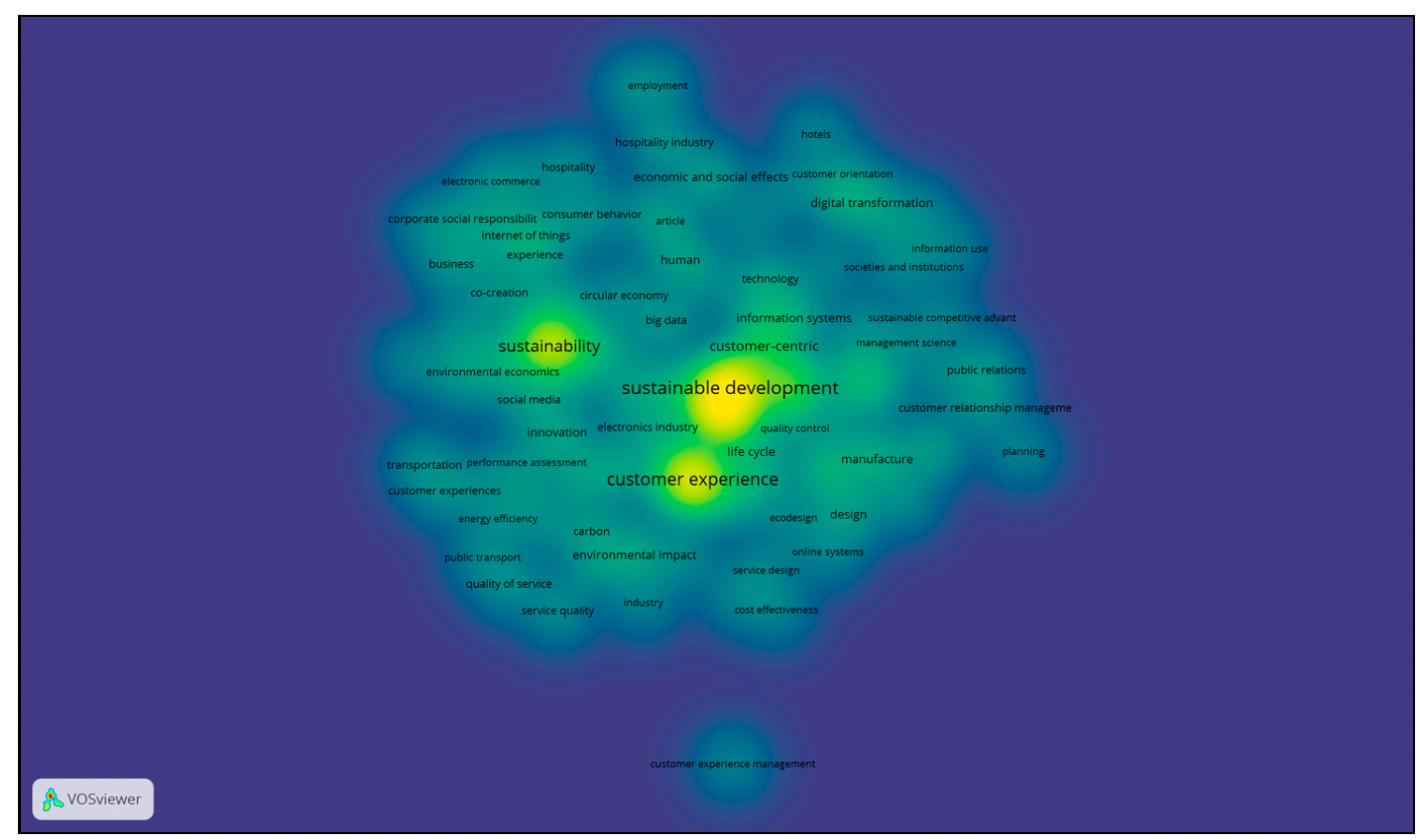

Figure 3. VOSviewer/Density Visualization.

It is very interesting to see in Figure 4 how the concepts of customer centricity, quality control, and product design are developed first chronologically. In a second stage, concepts such as sustainable development, use of information, and human behavior begin to emerge. To finally get as a new trend (see Cluster 3 in Figure 2) e-commerce, internet of things, circular economy, and customer experience management.

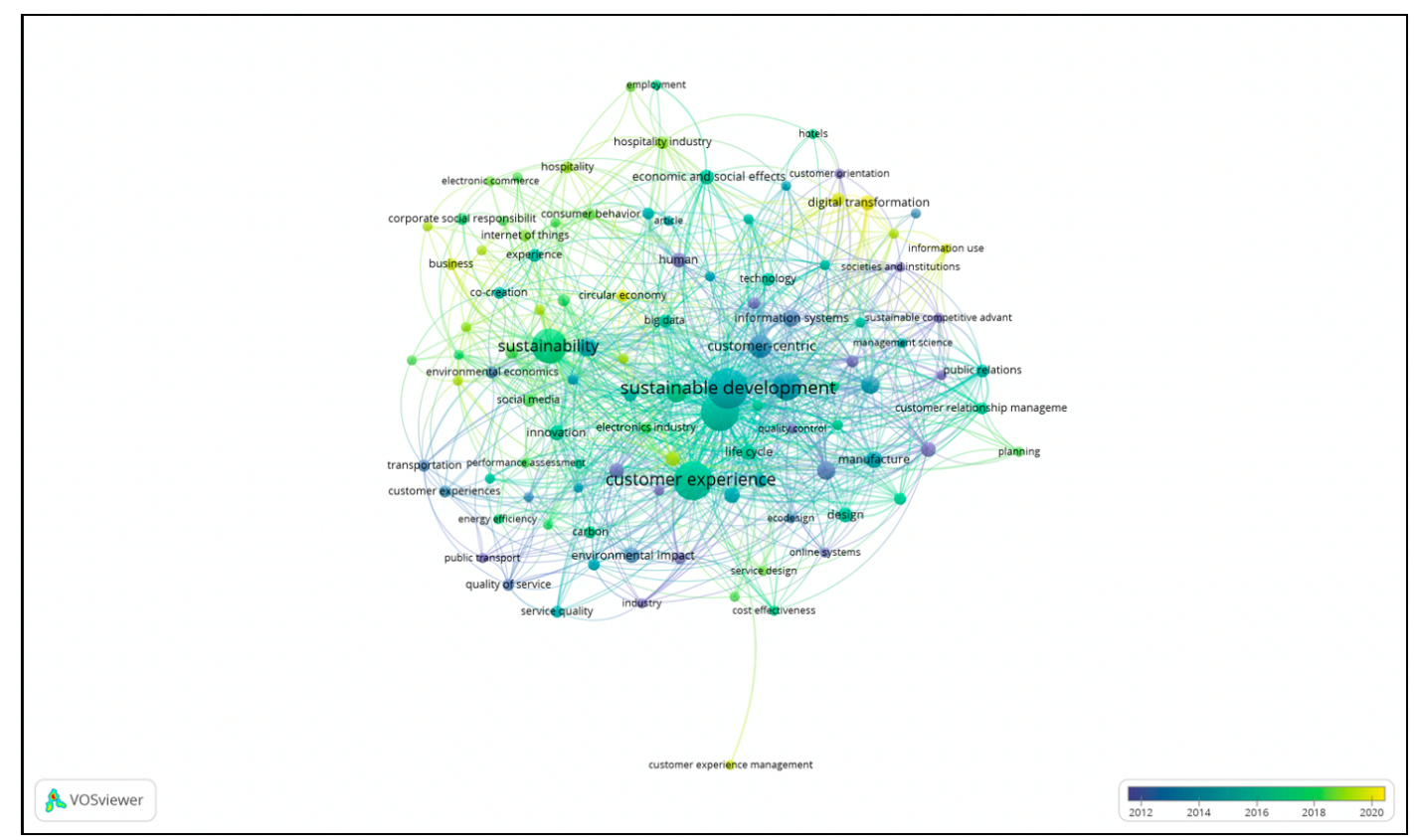

Figure 4. VOSviewer/Chronological Visualization.

Finally, it can be seen clearly, as, in one hand, Figure 3 shows the most repeated keywords, and on the other hand, Figure 4 shows the most recent concepts. 


\subsection{Subject Area}

Figure 5 concludes that the discipline that most develops the concepts seen above are "Business, Management and Accounting", because Marketing, from which everything related to the customer-centric perspective is derived mainly. The second discipline is "Engineering" since it is part of the same area that develops sustainability issues. Along the same lines, the third discipline is "Computer Science" for everything related to information technology and big data. Finally, the fourth discipline is "Social Sciences", as they are part of the common area of management and marketing [82].

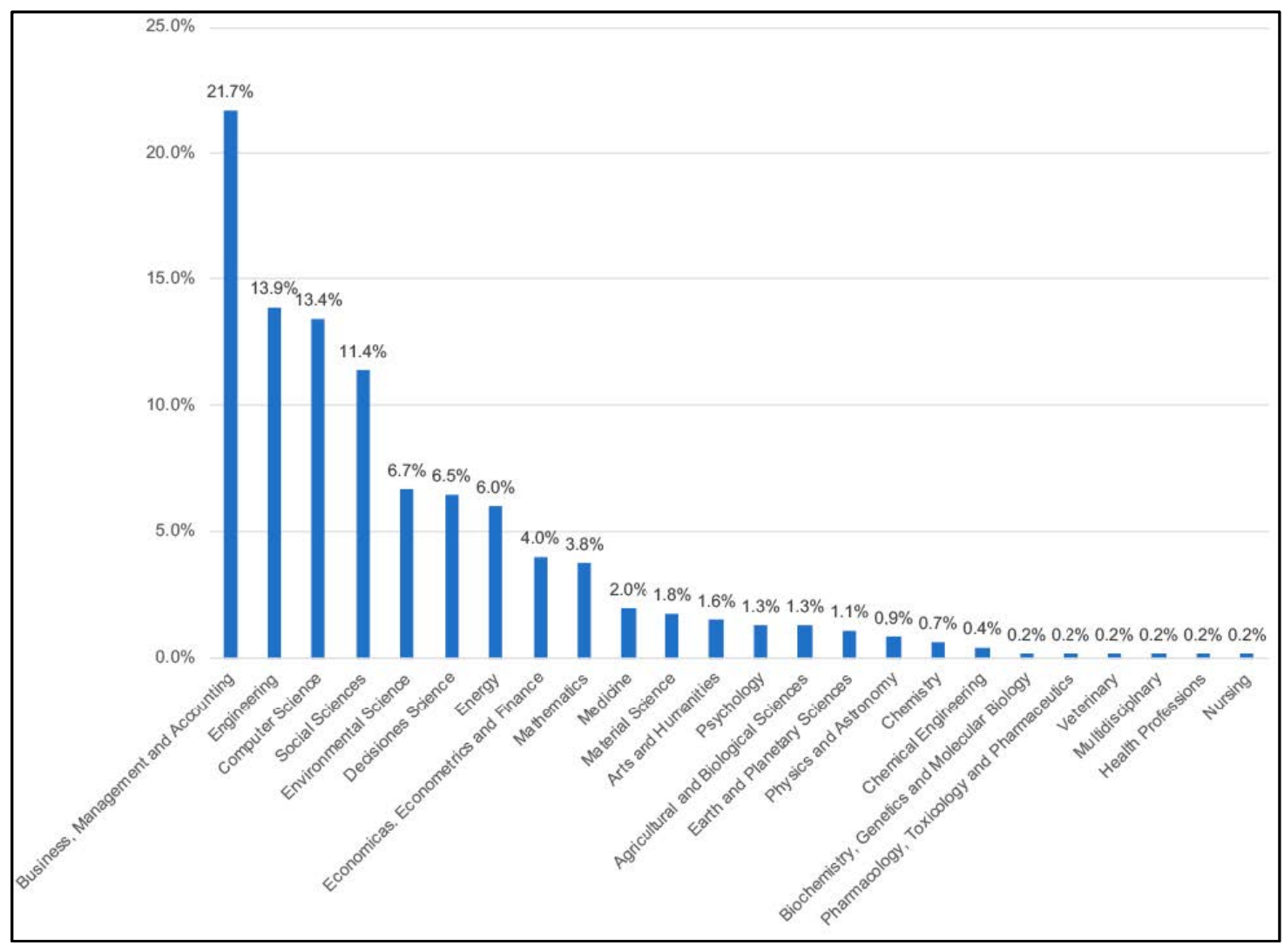

Figure 5. Subject Area Distribution.

\subsection{Remarkable Authors, Countries' Participation, and Leading Institutions and Sources}

Table 4 shows the top 11 journals, with the total number of documents, citations, and the average number of citations per paper. The first journal on the list is "Sustainability" with eight documents. They were analyzed taking into account the CiteScore Percentile which assesses the impact of citations in the last 3 years, with 99th being the highest percentile and 0th being the lowest [83], and the SJR 2018, which assesses the weight of citations taking into account the subject of the journal and its prestige [84]. Considering the above, it is very interesting how 8 of the 11 journals are in Q1 of the CiteScore Percentile and two of them- "Business Strategy and the Environment" and "Industrial Management and Data Systems" - are even on the 99th CiteScore Percentile. In this specific case, there does not seem to be a direct relationship between the "Average citation per document" and the weight in the CiteScore Percentile, which shows the academic weight of the journals used in this document with objective criteria.

As pointed out by Esfahani [85], it is also important to evaluate the authors, universities, and countries as those are a valuable reference points in order to map the available customer centricity and sustainability literature. Table 5 shows the authors with more than 53 citations in the research. Table 6 shows the first 10 institutions that produced the most documents, and it is interesting to note that the second in the number of papers is not a university, but an automobile manufacturing company, 
which shows the relevance in the world of the industry of the relationship between the "custom-centric" perspective and "sustainability". Table 7 shows the 10 countries with the most papers produced, taking into account that the United States, the first in the list, produced more documents than the sum of the second and third in the list: China and India. It is important to note that no authors and almost no institutions are involved in this topic repeatedly. This is interesting, as researchers and their teams usually specialize in some topics which are repeatedly analyzed and discussed. Therefore, we can conclude that the interest in this topic is very sporadic and/or inconsistent.

Table 4. Principal Journals.

\begin{tabular}{|c|c|c|c|c|c|}
\hline Source & TP & TC & C/D & $\begin{array}{c}\text { SJR } \\
2019\end{array}$ & $\begin{array}{l}\text { CiteScore } \\
\text { Percentile }\end{array}$ \\
\hline Sustainability (Switzerland) & 8 & 25 & 313 & 0.581 & 80th \\
\hline Journal of Service Management & 2 & 96 & 4800 & 1.710 & 97th \\
\hline International Journal of Hospitality Management & 2 & 60 & 3000 & 2.217 & 97th \\
\hline International Journal of Operations and Production Management & 2 & 54 & 2700 & 2.187 & 96th \\
\hline Journal of Retailing and Consumer Services & 2 & 42 & 2100 & 1.338 & 90th \\
\hline Business Strategy and the Environment & 2 & 41 & 2050 & 1.828 & 98th \\
\hline Industrial Management and Data Systems & 2 & 27 & 1350 & 1.390 & 99th \\
\hline SAE Technical Papers & 2 & 13 & 650 & 0.317 & 40th \\
\hline Journal of Business Research & 2 & 8 & 400 & 1.871 & 95th \\
\hline IFIP Advances in Information and Communication Technology & 2 & 5 & 250 & 0.209 & 30th \\
\hline
\end{tabular}

Note: TP = Total Papers; TC = Total Citations; $\mathrm{C} / \mathrm{D}$ = Average citation per document; SJR = Scimago Journal Rank in 2019.

Table 5. Authors.

\begin{tabular}{ccc}
\hline Author & TP $^{\mathbf{1}}$ & TC $^{\mathbf{2}}$ \\
\hline Sethia N.K. & 1 & 381 \\
Sheth J.N. & 1 & 381 \\
Srinivas S. & 1 & 381 \\
Chan E.S.W. & 2 & 127 \\
Chathoth P.K. & 1 & 122 \\
Harrington R.J. & 1 & 122 \\
Ungson G.R. & 1 & 122 \\
Verleye K. & 2 & 109 \\
Avery G.C. & 1 & 65 \\
Bergsteiner H. & 1 & 65 \\
Chang K.C. & 1 & 61 \\
Huang M.H. & 1 & 53 \\
Rust R.T. & 1 & 53 \\
\hline TP & Total Papers; TC & $=$ Total Citations.
\end{tabular}

Table 6. Institutions.

\begin{tabular}{ccc}
\hline Affiliation & TP $^{\mathbf{1}}$ & TC $^{\mathbf{2}}$ \\
\hline Bina Nusantara University & 4 & 0 \\
General Motors & 3 & 14 \\
Universiti Teknologi MARA & 3 & 6 \\
Michigan State University & 3 & 1 \\
University of Johannesburg & 3 & 2 \\
University of Sheffield & 2 & 11 \\
University of Calgary & 2 & 3 \\
University of Northumbria & 2 & 11 \\
National Taiwan University & 2 & 53 \\
California Polytechnic State University & 2 & 382 \\
\hline
\end{tabular}

Explanation: $\mathrm{TP}^{1}=$ Total Papers; $\mathrm{TC}^{2}=$ Total Citations. 
Table 7. Countries.

\begin{tabular}{lcc}
\hline \multicolumn{1}{c}{ Affiliation } & $\mathbf{T P}^{\mathbf{1}}$ & $\mathbf{T C}^{\mathbf{2}}$ \\
\hline United States & 50 & 899 \\
China & 22 & 96 \\
India & 19 & 21 \\
United Kingdom & 17 & 133 \\
Taiwan & 12 & 202 \\
Italy & 10 & 46 \\
Australia & 8 & 114 \\
Indonesia & 8 & 4 \\
France & 7 & 29 \\
Malaysia & 7 & 16 \\
\hline Explanation: $\mathrm{TP}^{1}=$ Total Papers; & $\mathrm{TC}^{2}=$ Total Citations.
\end{tabular}

Regarding the citations by country, it is important to note that the sum of the second to the tenth country (661 citations) does not reach the citations of the first in the list, the United States (899 citations), which shows that it is country is at the forefront in the investigation of this subject. Finally, regarding the number of citations, as seen in Table 2, the 3 most cited papers affect a significant percentage of the total citations.

\subsection{Case Studies' Analysis}

Case studies are very valuable for practitioners as this methodology presents not only how and why things happen, but also the differences between what was planned and what actually occurred in contemporary phenomena [86]. For this reason, we identified, categorize, and analyze all the case-study research on the 218 documents of the bibliometric analysis. Initially, Figure 6 shows all the case studies according to the methodology implemented. From the 41 case studies founded, 27 cases use a qualitative methodology, 9 use a quantitative methodology, and 5 cases use a mixed methodology.

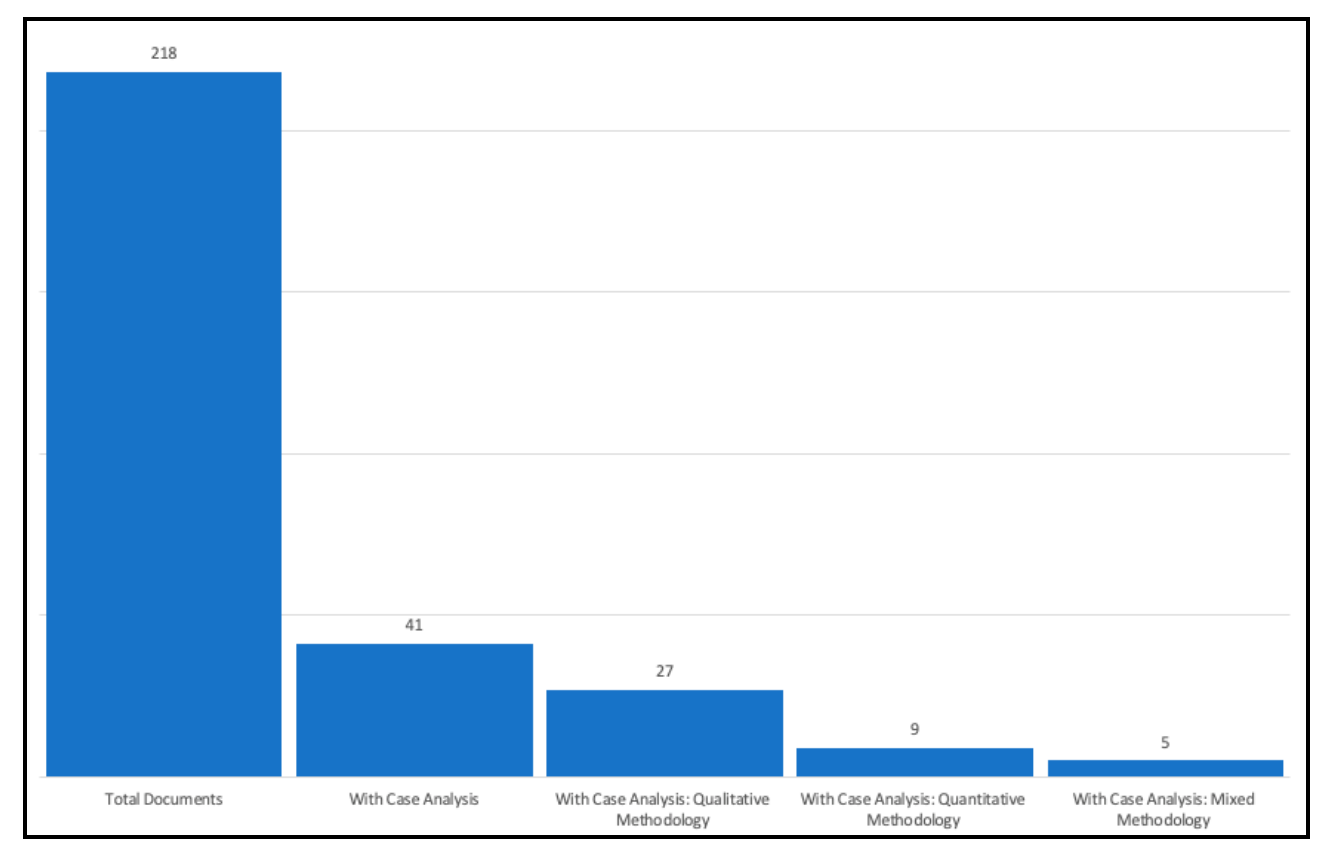

Figure 6. Documents with Case Analysis and General Methodology.

Analyzing in more depth, in Figure 7, it is seen how a great variety of alternatives are used to develop the research, which gives a good number of options to integrate sustainability and customer-centricity 
perspective in organizations. In the 41 articles used, the methodologies described are, among others, frameworks, Interviews, Quantitative Models, Surveys, Cluster Correlations, and Simulations.

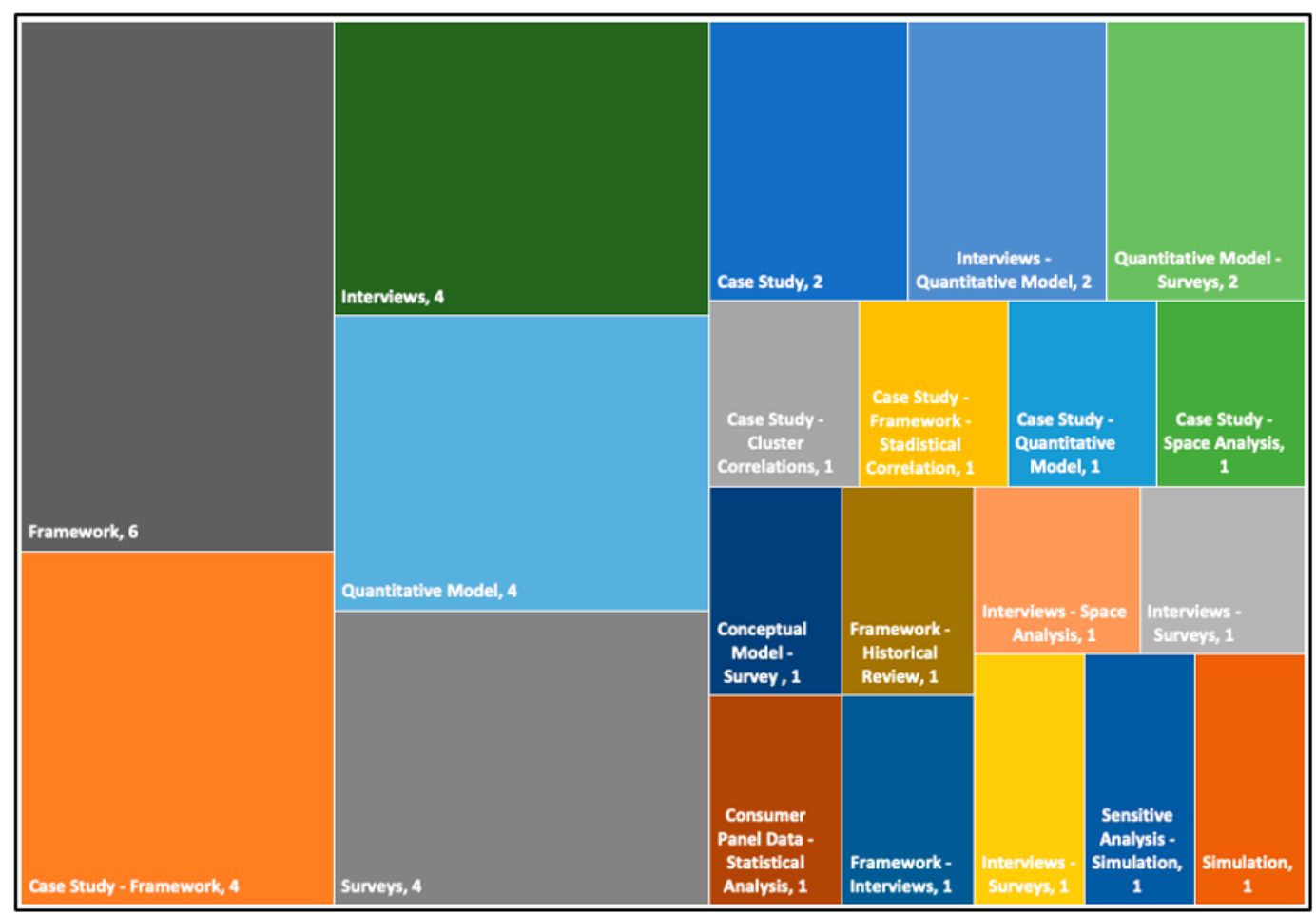

Figure 7. Case Analysis Documents by Methodology Description.

Along the same lines, in the 41 case studies covered, as seen in Figure 8, there are a large number of different industries: Hospitality, Healthcare, Logistics, Retail, Fashion, Technology, etc. The foregoing gives a more holistic perspective regarding the results of this research.

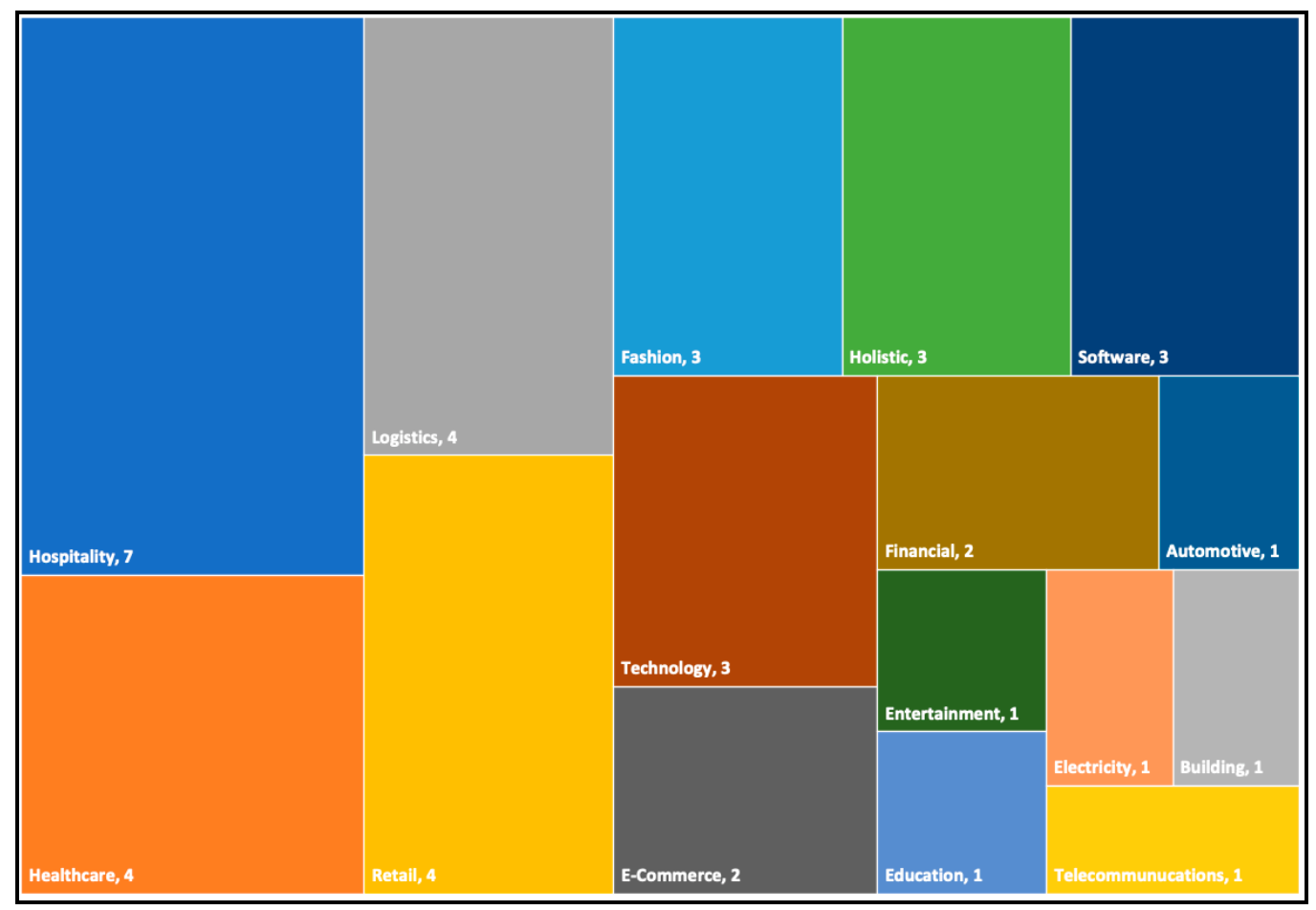

Figure 8. Case Analysis Documents by Industry. 
Taking into account the results of these 41 papers, the most relevant ones, and with the most citations, were identified in order to be able to make suggestions to practitioners regarding the search for sustainability and customer centricity in their respective firms.

The search for the real purpose for business and develop a business model with a social goal is shown to be essential to achieve the above [10,87], without forgetting the stakeholder view [88], and that profits are not the only thing necessary to create value [89], be coherent with the corporate purpose [13]. In addition, it is shown that when looking after the environment is good for profit [90], and to get the loyalty of customers [60,91]. The economic and environmental aspects cannot be differentiated [92,93]; it is an intangible experience which consumers perceive [94].

Other good suggestions for practitioners are the implementation of a circular business model [95], the integration of a brand experience that explicitly includes sustainability [74], and that the use of big data and quick access to information prevents failure in the customer service [96].

\section{Conclusions and Future Research}

This paper shows mapping research of the customer-centric perspective and sustainability in organizations. To carry out the investigation, the Web of Science and Scopus databases were used, and 218 documents were analyzed, 1589 keywords were identified, of which 106 were used in the deep analysis since they fulfilled the requirement of having at least three occurrences. The period ranging was from 1990 to 31 July 2020. For bibliometric analysis, the VOSviewer program, the Web of Science data, and the Scopus information were used.

The research, in the study subjects, grows in an accelerated way, since it went from 5 papers in 2005, 5 in 2010, 17 in 2015, and 45 in 2019.

The year with the highest number of publications was 2019, and the paper with the greatest impact is "Mindful consumption: A customer-centric approach to sustainability" published by Sheth, Sethia, and Sriniva [10], who are, in turn, the authors with the highest number of citations.

Within the keyword analysis, three clusters were identified: the first focused on "Sustainable Development" and "Customer-Centric Perspective" and its relationship to "Customer Satisfaction"; the second shows the "Sustainability" understood as "Triple Bottom Line"; the third develops trends as in recent years as e-commerce, the internet of things, circular economy, and design thinking.

The dominant disciplines in the documents are "Business, Management, and Accounting", "Engineering", and "Computer Science". Additionally, within these subjects, the most relevant journals are "Journal of Service Management", "International Journal of Hospitality Management", "International Journal of Operations and Production Management", "Journal of Retailing and Consumer Services", and "Business Strategy and the Environment". The institutions with the most publications were "Bina Nusantura University", "General Motors", "University Teknology MARA", and "Michigan State University". The country that is far ahead in these issues is the United States, followed by India, and China.

In addition, based on the case analysis, the industries studied were identified, the main methodologies were shown, and some ideas were suggested to the practitioners. Corporate purpose was also identified as a theme that helps to achieve sustainability and a customer-centric perspective.

This research topic was chosen, to the best of our knowledge, as it has not been previously discussed and is relevant to advance the customer as the center of organizations and at the same time find economic, environmental, and people sustainability in the long term.

Finally, in subsequent investigations, it will be interesting to propose a methodology to fully integrate the corporate purpose together with the sustainability and customer centricity approaches, since in this paper some contributions in this field were highlighted.

Author Contributions: Conceptualization, S.P.-J., A.M.-V., I.O., and R.R.; methodology, S.P.-J., and A.M.-V.; software, S.P.-J.; validation, S.P.-J., A.M.-V., and I.O.; formal analysis, S.P.-J.; investigation, S.P.-J.; resources, S.P.-J.; data curation, S.P.-J.; writing—original draft preparation, S.P.-J. and A.M.-V.; writing—review and editing, S.P.-J., A.M.-V., I.O., and R.R.; visualization, S.P.-J. and A.M.-V.; supervision, A.M.-V., I.O., and R.R.; project administration, 
S.P.-J. and A.M.-V.; funding acquisition, S.P.-J., A.M.-V., I.O., and R.R. All authors have read and agreed to the published version of the manuscript.

Funding: This research did not receive external funding and the APC was funded by Universidad de La Sabana.

Conflicts of Interest: Pardo-Jaramillo, S., Muñoz-Villamizar, A., Osuna, I., and Roncancio, R. declare no conflict of interest and the funders are themselves.

\section{References}

1. Sheth, J.N.; Sisodia, R.S.; Sharma, A. The antecedents and consequences of customer-centric marketing. J. Acad. Mark. Sci. 2000, 28, 55-66. [CrossRef]

2. Gaurav, R.; Shainesh, G. The Changing Face of Customer Centricity; Palgrave Macmillan: London, UK, 2016.

3. Santos, J.; Muñoz-Villamizar, A.; Ormazábal, M.; Viles, E. Using problem-oriented monitoring to simultaneously improve productivity and environmental performance in manufacturing companies. Int. J. Comput. Integr. Manuf. 2019, 32, 183-193. [CrossRef]

4. Girard, F.F. Symbioses strategies for sustainable company management. Int. J. Sustain. Dev. 2009, 12, $248-263$. [CrossRef]

5. Özcüre, G.; Demirkaya, H.; Eryiğit, N. The sustainable company and employee participation as a part of the solution to triple crisis in the European Union and Turkey: Example of OMV Samsun Elektrik. Procedia Soc. Behav. Sci. 2011, 24, 1274-1287.

6. Välikangas, L.; Gibbert, M. Boundary-setting strategies for escaping innovation traps. MIT Sloan Manag. Rev. 2005, 46, 58-68.

7. Jeppesen, L.B.; Lakhani, K.R. Marginality and problem-solving effectiveness in broadcast search. Organ. Sci. 2010, 21, 1016-1033. [CrossRef]

8. Jiao, J. Design Economics of Product Platforms for Enterprise Sustainability Towards Mass Customization. In Proceedings of the 2009 16th International Conference on Industrial Engineering and Engineering Management, Beijing, China, 21-23 October 2009; pp. 1714-1718.

9. Chavez, R.; Yu, W.; Feng, M.; Wiengarten, F. The Effect of Customer-Centric Green Supply Chain Management on Operational Performance and Customer Satisfaction. Bus. Strateg. Environ. 2016, 25, 205-220. [CrossRef]

10. Sheth, J.N.; Sethia, N.K.; Srinivas, S. Mindful consumption: A customer-centric approach to sustainability. J. Acad. Mark. Sci. 2011, 39, 21-39. [CrossRef]

11. Mutingi, M.; Mbohwa, C.; Mapfaira, H. Sustainable Product Innovation for Customer Experience: A Conceptual Framework. In Proceedings of the International Conference on Industrial Engineering and Operations Management, IEOM Society, Kuala Lumpur, Malaysia, 8-10 March 2016; pp. 2182-2187.

12. Jeffers, P.I. Embracing sustainability: Information technology and the strategic leveraging of operations in third-party logistics. Int. J. Oper. Prod. Manag. 2010, 30, 260-287. [CrossRef]

13. Hollensbe, E.; Wookey, C.; Hickey, L.; George, G. Organizations with purpose. Acad. Manag. J. 2014, 57, 1227-1234.

14. Merigó, J.M.; Muller, C.; Modak, N.M.; Laengle, S. Research in Production and Operations Management: A University-Based Bibliometric Analysis. Glob. J. Flex. Syst. Manag. 2019, 20, 1-29.

15. Rethinking Market Orientation from the Outside in. Available online: https://www.msi.org/working-papers/ rethinking-market-orientation-from-the-outside-in-2/ (accessed on 18 May 2020).

16. Lee, Y.-C. Corporate Sustainable Development and Marketing Communications on Social Media: Fortune 500 Enterprises. Bus. Strateg. Environ. 2017, 26, 569-583. [CrossRef]

17. Drucker, P.F. The Practice of Management; Harper \& Row: New York, NY, USA, 1954; ISBN 0060913169.

18. Abbott, L. Quality and Competition: An Essay in Economic Theory; Columbia University Press: New York, NY, USA, 1955; p. 229.

19. Levitt, T. The Marketing Imagination; Collier Macmillan: London, UK, 1986.

20. Narver, J.C.; Slater, S.F. The Effect of a Market Orientation on Business Profitability. J. Mark. 1990, 54, $20-35$. [CrossRef]

21. Kohli, A.K.; Jaworski, B.J. Market Orientation: The Construct, Research Propositions, and Managerial Implications. J. Mark. 1990, 54, 1-18. [CrossRef]

22. Krasnikov, A.; Jayachandran, S. The Relative Impact of Marketing, Research-and-Development, and Operations Capabilities on Firm Performance. J. Mark. 2008, 72, 1-11. 
23. Morgan, N.A.; Rego, L.L. The Value of Different Customer Satisfaction and Loyalty Metrics in Predicting Business Performance. Mark. Sci. 2006, 25, 426-439.

24. Gruca, T.S.; Rego, L.L. Customer Satisfaction, Cash Flow, and Shareholder Value. J. Mark. 2005, 69, $115-130$.

25. Fang, E.; Palmatier, R.W.; Steenkamp, J.-B.E.M. Effect of Service Transition Strategies on Firm Value. J. Mark. 2008, 72, 1-14.

26. Nobre, F.S. Core competencies of the new industrial organization. J. Manuf. Technol. Manag. 2011, 22, $422-443$. [CrossRef]

27. Christensen, C.M. The Innovator's Dilemma: The Revolutionary National Bestseller that Changed the Way We Do Business; Harper Collins: New York, NY, USA, 2003; ISBN 0060521996.

28. Gulati, R.; Oldroyd, J. The quest for customer focus. Harv. Bus. Rev. 2005, 83, 92-101.

29. Fader, P. Customer Centricity: Focus on the Right Customers for Strategic Advantage; Wharton Digital Press: Philadelphia, PA, USA, 2012.

30. Lee, J.Y.; Kozlenkova, I.V.; Palmatier, R.W. Structural marketing: Using organizational structure to achieve marketing objectives. J. Acad. Mark. Sci. 2015, 43, 73-99. [CrossRef]

31. Lee, J.-Y.; Sridhar, S.; Henderson, C.M.; Palmatier, R.W. Effect of Customer-Centric Structure on Long-Term Financial Performance. Mark. Sci. 2015, 34, 250-268. [CrossRef]

32. Coronado, M. Business Sustainability Game Changers. Available online: https://blog.euromonitor.com/ business-sustainability-game-changers/ (accessed on 18 May 2020).

33. Lubin, D.A.; Esty, D.C. The sustainability imperative. Harv. Bus. Rev. 2010, 88, 42-50.

34. Brundtland, G. Our Common Future: Report of the 1987 World Commission on Environment and Development; United Nations: Oslo, Norway, 1987.

35. Enders, J.C.; Remig, M. Theories of Sustainable Development; Taylor and Francis Inc.: London, UK, 2014; ISBN 9781138796362.

36. Elkington, J. Partnerships from cannibals with forks: The triple bottom line of 21st-century business. Environ. Qual. Manag. 1998, 8, 37-51. [CrossRef]

37. Newport, D.; Chesnes, T.; Lindner, A. The "environmental sustainability" problem: Ensuring that sustainability stands on three legs. Int. J. Sustain. High. Educ. 2003, 4, 357-363. [CrossRef]

38. Porter, M.E.; Kramer, M.R. Creating Shared Value. Harv. Bus. Rev. 2011, 89, 62-77.

39. Hoffman, A.J.; Woody, J.G. Climate Change: What's Your Business Strategy? Harvard Business Press: Boston, MA, USA, 2008; ISBN 9781422121054.

40. Ozturan, P.; Tuton, W. The Socially Responsible CMO. Available online: https://jw6d-wdmm.accessdomain. com/reports/the-socially-responsible-cmo/ (accessed on 19 May 2020).

41. Ferrell, O.C.; Gonzalez-Padron, T.L.; Hult, G.T.M.; Maignan, I. From market orientation to stakeholder orientation. J. Public Policy Mark. 2010, 29, 93-96. [CrossRef]

42. Pritchard, A. Statistical bibliography or bibliometrics. J. Doc. 1969, 25, 348-349.

43. Pourkhani, A.; Abdipour, K.; Baher, B.; Moslehpour, M. The impact of social media in business growth and performance: A scientometrics analysis. Int. J. Data Netw. Sci. 2019, 3, 223-244. [CrossRef]

44. Zemigala, M. Tendencies in research on sustainable development in management sciences. J. Clean. Prod. 2019, 218, 796-809. [CrossRef]

45. Bensalem, A.; Kin, V. A bibliometric analysis of reverse logistics from 1992 to 2017. Supply Chain Forum 2019, 20, 15-28. [CrossRef]

46. Gaviria-Marin, M.; Merigó, J.M.; Baier-Fuentes, H. Knowledge management: A global examination based on bibliometric analysis. Technol. Forecast. Soc. Change 2019, 140, 194-220. [CrossRef]

47. Muñoz-Villamizar, A.; Solano, E.; Quintero-Araujo, C.; Santos, J. Sustainability and digitalization in supply chains: A bibliometric analysis. Uncertain Supply Chain Manag. 2019, 7, 703-712. [CrossRef]

48. Web of Science: Confident Research Begins here. Available online: https:/clarivate.com/webofsciencegroup/ solutions/web-of-science/ (accessed on 28 August 2020).

49. About Scopus: Elsevier. Available online: https://www.elsevier.com/en-in/solutions/scopus (accessed on 17 May 2020).

50. Van Eck, N.J.; Waltman, L. Software survey: VOSviewer, a computer program for bibliometric mapping. Scientometrics 2010, 84, 523-538. [CrossRef] [PubMed]

51. Noyons, E.C.M.; Moed, H.F.; Luwel, M. Combining mapping and citation analysis for evaluative bibliometric purposes: A bibliometric study. J. Am. Soc. Inf. Sci. 1999, 50, 115-131. [CrossRef] 
52. Small, H. Visualizing science by citation mapping. J. Am. Soc. Inf. Sci. 1999, 50, 799-813. [CrossRef]

53. Johnson, L. Quality: How to meet customer demands in a process from design to disposal. J. Occup. Accid. 1990, 13, 167-170. [CrossRef]

54. Verleye, $\mathrm{K}$. The co-creation experience from the customer perspective: Its measurement and determinants. J. Serv. Manag. 2015, 26, 321-342. [CrossRef]

55. Chathoth, P.K.; Ungson, G.R.; Harrington, R.J.; Chan, E.S.W. Co-creation and higher order customer engagement in hospitality and tourism services: A critical review. Int. J. Contemp. Hosp. Manag. 2016, 28, 222-245. [CrossRef]

56. Avery, G.C.; Bergsteiner, H. Sustainable leadership practices for enhancing business resilience and performance. Strateg. Leadersh. 2011, 39, 5-15. [CrossRef]

57. Chang, K.-C. Effect of servicescape on customer behavioral intentions: Moderating roles of service climate and employee engagement. Int. J. Hosp. Manag. 2016, 53, 116-128. [CrossRef]

58. Huang, M.-H.; Rust, R.T. IT-Related Service: A Multidisciplinary Perspective. J. Serv. Res. 2013, 16, 251-258. [CrossRef]

59. McDonald, L.M.; Lai, C.H. Impact of corporate social responsibility initiatives on Taiwanese banking customers. Int. J. Bank Mark. 2011, 29, 50-63. [CrossRef]

60. Chen, R.J.C. From sustainability to customer loyalty: A case of full service hotels' guests. J. Retail. Consum. Serv. 2015, 22, 261-265. [CrossRef]

61. Zhang, W.; Li, J.; Sha, Z.; Wang, X. Customer Experience Management Models: Perspectives from Environment, Psychology and Strategy. In Proceedings of the 2010 International Conference on Management and Service Science, Wuhan, China, 24-26 August 2010.

62. Pan, S.; Giannikas, V.; Han, Y.; Grover-Silva, E.; Qiao, B. Using customer-related data to enhance e-grocery home delivery. Ind. Manag. Data Syst. 2017, 117, 1917-1933. [CrossRef]

63. De Wilde, M.; Spaargaren, G. Designing trust: How strategic intermediaries choreograph homeowners' low-carbon retrofit experience. Build. Res. Inf. 2019, 47, 362-374. [CrossRef]

64. Bradigan, P.S.; Rodman, R.L. Single service point: It's all in the design. Med. Ref. Serv. Q. 2008, 27, 367-378. [CrossRef]

65. Kumar, J.; Graf, P. Future Centered Design: Designing for Sustainable Business. In Lecture Notes in Computer Science; Springer: Berlin/Heidelberg, Germany, 2011; Volume 6769, pp. 449-457. [CrossRef]

66. Cedeño, J.M.V.; Hannola, L.; Ojanen, V. Knowledge Requirements for Sustainable Smart Service Design. In Proceedings of the 11th International Joint Conference on Knowledge Discovery, Knowledge Engineering and Knowledge Management, Vienna, Austria, 17-19 September 2019.

67. Susniene, D.; Jurkauskas, A.; Prunskiene, J. Public Transport System and Its Challenges for Sustainability. In Proceedings of the 3rd International Workshop-Intelligent Technologies in Logistics and Mechatronics Systems ITELMS 2008, Panevezys, Lithuania, 22-23 May 2018; pp. 65-70.

68. Faizi, R.; Fkihi, S.E.; Afia, A.E. Leveraging Big Data to Improve Customer Experience. Available online: https://ibima.org/accepted-paper/leveraging-big-data-improve-customer-experience/ (accessed on 19 May 2020).

69. Ban, H.-J.; Choi, H.; Choi, E.-K.; Lee, S.; Kim, H.-S. Investigating key attributes in experience and satisfaction of hotel customer using online review data. Sustainability 2019, 11, 6570. [CrossRef]

70. Lovrić, M.; Li, T.; Vervest, P. Sustainable revenue management: A smart card enabled agent-based modeling approach. Decis. Support Syst. 2013, 54, 1587-1601. [CrossRef]

71. Feng, L.; Sun, B.; Wang, K.; Tsai, S.-B. An empirical study on the design of digital content products from a big data perspective. Sustainability 2018, 10, 3092. [CrossRef]

72. Kazak, A.N.; Chetyrbok, P.V.; Oleinikov, N.N. Artificial Intelligence in the Tourism Sphere. In IOP Conference Series: Earth and Environmental Science, Krasnoyars, Russian Federation; Institute of Physics Publishing: Bristol, UK, 2020; Volume 421.

73. Mu, J.; Zhang, J.Z.; Gilliland, D. No Silver Bullet with AI: Blending in Firm Culture and Capabilities with AI Marketing Investment for Enhancing Firm Performance. Available online: https://www.msi.org/working-papers/no-silver-bullet-with-ai-blending-in-firm-culture-andcapabilities-with-ai-marketing-investment-for-enhancing-firm-performance-2/ (accessed on 18 May 2020).

74. Larke, R.; Kilgour, M.; O'Connor, H. Build touchpoints and they will come: Transitioning to omnichannel retailing. Int. J. Phys. Distrib. Logist. Manag. 2018, 48, 465-483. [CrossRef] 
75. Lee, J.; Palmatier, R.W. Creating and Appropriating Alliance Value through Customer-Centric Structures. Available online: https://www.msi.org/working-papers/creating-and-appropriating-alliance-value-throughcustomercentric-structures/ (accessed on 20 May 2020).

76. Yakhlef, A. Customer experience within retail environments: An embodied, spatial approach. Mark. Theory 2015, 15, 545-564. [CrossRef]

77. Schallehn, H.; Seuring, S.; Strähle, J.; Freise, M. Customer experience creation for after-use products: A product-service systems-based review. J. Clean. Prod. 2019, 210, 929-944. [CrossRef]

78. Carta, S.; De Kock, P. Reifying luxury, gold to golden: How the showroom became a digital showreel, from object (gold) to experience (golden)—Experiencing luxury by abstracting the object. J. Des. Bus. Soc. 2019, 5, 193-206. [CrossRef]

79. Lauren, B.S. Mapping the Workspace of a Globally Distributed "Agile" Team; IGI Global: Hershey, PA, USA, 2015; Volume 7, ISBN 9781522519195.

80. Tian, M. The in-depth marketing environment of cross-border e-commerce experience stores. Ekoloji 2019, 28, 2861-2864.

81. Ullah, A.; Aimin, W.; Ahmed, M. Smart automation, customer experience and customer engagement in electric vehicles. Sustainability 2018, 10, 1350. [CrossRef]

82. List of Scopus Subject Areas. Available online: https://service.elsevier.com/app/answers/detail/a_id/15181/ supporthub/scopus/related/1/session/ (accessed on 25 May 2020).

83. CiteScore Metrics. Available online: https://blog.scopus.com/posts/citescore-2018-metrics-now-available (accessed on 27 May 2020).

84. About Scimago Journal \& Country Rank. Available online: https://www.scimagojr.com/aboutus.php (accessed on 27 May 2020).

85. Esfahani, H.J.; Tavasoli, K.; Jabbarzadeh, A. Big data and social media: A scientometrics analysis. Int. J. Data Netw. Sci. 2019, 3, 145-164. [CrossRef]

86. Noor, K. Case Study: A Strategic Research Methodology. Am. J. Appl. Sci. 2008, 5, 1602-1604. [CrossRef]

87. Pels, J.; Kidd, T.A. Business model innovation learning from a high-tech-low-fee medical healthcare model for the BOP. Int. J. Pharm. Healthc. Mark. 2015, 9, 200-218. [CrossRef]

88. Iyer, E.S.; Bhattacharya, C.B. Marketing and society: Preface to special section on volunteerism, price assurances, and direct-to-consumer advertising. J. Bus. Res. 2011, 64, 59-60. [CrossRef]

89. Drucker, P.F. Management: Tasks, Responsibilities, Practices; Harper Collins: New York, NY, USA, 1973.

90. Loeb, B.; Kockelman, K.M. Fleet performance and cost evaluation of a shared autonomous electric vehicle (SAEV) fleet: A case study for Austin, Texas. Transp. Res. Part A Policy Pract. 2019, 121, 374-385. [CrossRef]

91. Shen, C.-C.; Liu, D.-J. Correlation between the homestay experience and brand equity using the yuehetang rural residence as a case study. J. Hosp. Tour. Technol. 2015, 6, 59-72. [CrossRef]

92. Rasouli, M.R.; Trienekens, J.J.M.; Kusters, R.J.; Grefen, P.W.P.J. A Dynamic Capabilities Perspective on Service-Orientation in Demand-Supply Chains. Procedia CIRP 2015, 30, 396-401. [CrossRef]

93. Melacini, M.; Tappia, E. A critical comparison of alternative distribution configurations in omni-channel retailing in terms of cost and greenhouse gas emissions. Sustainability 2018, 10, 307. [CrossRef]

94. Milman, A.; Zehrer, A.; Tasci, A.D.A. Measuring the components of visitor experience on a mountain attraction: The case of the Nordkette, Tyrol, Austria. Tour. Rev. 2017, 72, 429-447. [CrossRef]

95. Hankammer, S.; Brenk, S.; Fabry, H.; Nordemann, A.; Piller, F.T. Towards circular business models: Identifying consumer needs based on the jobs-to-be-done theory. J. Clean. Prod. 2019, 231, 341-358. [CrossRef]

96. Maguire, S.; Ojiako, U. Market-led systems development: When customers become users. Ind. Manag. Data Syst. 2008, 108, 173-190. [CrossRef]

(C) 2020 by the authors. Licensee MDPI, Basel, Switzerland. This article is an open access article distributed under the terms and conditions of the Creative Commons Attribution (CC BY) license (http://creativecommons.org/licenses/by/4.0/). 